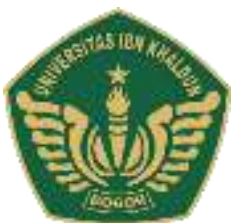

Diversity UIKA Bogor E-ISSN: 2776-9798

\section{Diversity}

JURNAL ILMIAH PASCASARJANA

http://ejournal.uika-bogor.ac.id/index.php/diversity

\title{
Persepsi, Pengambilan Keputusan, Konsep diri dan Values
}

\author{
Firdayanti B Hakim $^{a}$, Puteri Eka Yunita ${ }^{b}$, Dedi Supriyadic, Isbaya ${ }^{*}$, Amir \\ Tengku Ramly ${ }^{e}$ \\ a,b,c,d,e Univrsitas Ibn Khaldun, Indonesia \\ *Corresponding author e-mail: isbayasutrabayu@gmail.com
}

DOI : 10.32832/djip-uika.v1i3.3972

\begin{abstract}
ABSTRAK
Dalam sebuah organisasi yang terdiri dari berbagai macam orang dengan berbagai macam karakter yang berbeda, akan mengakibatkan kumpulan interaksi yang menciptakan sebuah budaya organisasi yang khas. Persepsi anggota organisasi berbeda-beda sesuai dengan motivasinya, demikian juga degan konsep diri dan value pada tiap individu akan menentukan bagaimana sebuah keputusan organisasi diambil. Organisasi yang ingin mencapai tujuannya secara efektif dan efisien harus bisa mengontrol factor-faktor yang mempengaruhi kualitas dari persepsi, konsep diri dan value dari tiap individu. Sehingga dapat memimimalisir konflik dan dapat mencapat tujuan organisasi sesuai yang direncanakan.
\end{abstract}

Kata kunci: Persepsi, konsepdiri, Pengambilan keputusan, Value

\section{Perception, Decision Making, Self-Concept and Values}

\begin{abstract}
In an organization consisting of various kinds of people with a variety of different characters, it will result in a collection of interactions that create a distinctive organizational culture. Perceptions of organizational members vary according to their motivation, as well as self-concept and values in each individual will determine how an organizational decision is taken. Organizations that want to achieve their goals effectively and efficiently must be able to control the factors that affect the quality of perceptions, self-concepts and values of each individual. So that it can minimize conflict and can achieve organizational goals as planned..
\end{abstract}

Keyword: Perception, self concept, Decision making, Value 


\section{PENDAHULUAN}

Persepsi merupakan suatu proses yang didahului oleh penginderaan, yaitu suatu stimulus yang diterima oleh individu melalui alat reseptor yaitu indera. Alat indera merupakan penghubung antara individu dengan dunia luarnya. Persepsi merupakan stimulus yang diindera oleh individu, diorganisasikan kemudian diinterpretasikan sehingga individu menyadari dan mengerti tentang apa yang diindera. Faktor-faktor yang mempengaruhi persepsi pada dasarnya dibagi menjadi 2 yaitu Faktor Internal dan Faktor Eksternal.

Faktor Internal yang mempengaruhi persepsi, yaitu faktor-faktor yang terdapat dalam diri individu, yang mencakup beberapa hal antara lain: Fisiologis. Informasi masuk melalui alat indera, selanjutnya informasi yang diperoleh ini akan mempengaruhi dan melengkapi usaha untuk memberikan arti terhadap lingkungan sekitarnya. Kapasitas indera untuk mempersepsi pada tiap orang berbeda-beda sehingga interpretasi terhadap lingkungan juga dapat berbeda. Perhatian. Individu memerlukan sejumlah energi yang dikeluarkan untuk memperhatikan atau memfokuskan pada bentuk fisik dan fasilitas mental yang ada pada suatu obyek. Energi tiap orang berbeda-beda sehingga perhatian seseorang terhadap obyek juga berbeda dan hal ini akan mempengaruhi persepsi terhadap suatu obyek. Minat. Persepsi terhadap suatu obyek bervariasi tergantung pada seberapa banyak energi atau perceptual vigilance yang digerakkan untuk mempersepsi. Perceptual vigilance merupakan kecenderungan seseorang untuk memperhatikan tipe tertentu dari stimulus atau dapat dikatakan sebagai minat. Kebutuhan yang searah. Faktor ini dapat dilihat dari bagaimana kuatnya seseorang individu mencari obyek-obyek atau pesan yang dapat memberikan jawaban sesuai dengan dirinya. Pengalaman dan ingatan. Pengalaman dapat dikatakan tergantung pada ingatan dalam arti sejauh mana seseorang dapat mengingat kejadian-kejadian lampau untuk mengetahui suatu rangsang dalam pengertian luas. Suasana hati. Keadaan emosi mempengaruhi perilaku seseorang, mood ini menunjukkan bagaimana perasaan seseorang pada waktu yang dapat mempengaruhi bagaimana seseorang dalam menerima, bereaksi dan mengingat. 
Faktor Eksternal yang mempengaruhi persepsi, merupakan karakteristik dari linkungan dan obyek-obyek yang terlibat di dalamnya. Elemen-elemen tersebut dapat mengubah sudut pandang seseorang terhadap dunia sekitarnya dan mempengaruhi bagaimana seseoarang merasakannya atau menerimanya. Sementara itu faktor-faktor eksternal yang mempengaruhi persepsi adalah Ukuran dan penempatan dari obyek atau stimulus. Faktor ini menyatakan bahwa semakin besrnya hubungan suatu obyek, maka semakin mudah untuk dipahami. Bentuk ini akan mempengaruhi persepsi individu dan dengan melihat bentuk ukuran suatu obyek individu akan mudah untuk perhatian pada gilirannya membentuk persepsi. Warna dari obyek-obyek. Obyek-obyek yang mempunyai cahaya lebih banyak, akan lebih mudah dipahami (to be perceived) dibandingkan dengan yang sedikit. Keunikan dan kekontrasan stimulus. Stimulus luar yang penampilannya dengan latarbelakang dan sekelilingnya yang sama sekali di luar sangkaan individu yang lain akan banyak menarik perhatian. Intensitas dan kekuatan dari stimulus. Stimulus dari luar akan memberi makna lebih bila lebih sering diperhatikan dibandingkan dengan yang hanya sekali dilihat. Kekuatan dari stimulus merupakan daya dari suatu obyek yang bisa mempengaruhi persepsi. Motion atau gerakan. Individu akan banyak memberikan perhatian terhadap obyek yang memberikan gerakan dalam jangkauan pandangan dibandingkan obyek yang dia.

Pengambilan keputusan melaksanakan keputusan dengan baik (A. Alimudin, 2017). Namun juga terdapat pengambilan keputusan yang tidak terprogram. Pengambilan keputusan tidak terprogram ialah pengambilan keputusan yang problemnya unik, belum pernah terjadi. Informasi mengenai problem belum tersedia atau sedikit,peraturan, kebijakan, prosedur operasi standar untuk membuat keputusan yang belum ada (Wirawan, 2014).

Menurut Herbert A. Simon mengemukakan tiga proses dalam pengambilan keputusan yaitu: $\quad$ (1) Inteligence Activity, yaitu : proses pemilihan situasi dan kondisi dengan wawasan yang inteligen; (2) Design Activity, aitu proses menemukan masalah, mengembangkan pemahaman dan menganalisis kemungkinan pemecahan masalah serta tindakan lebih lanjut, ada perencanaan pola kegiatan; dan (3) Choise Activity, yaitu memilih salah satu tindakan dari sekian banyak alternative atau kemungkinan pemecahan, dan diambil keputusan.

Gaya dalam pengambilan keputusan menurut Stephen Robbins (2006), adalah: (1) gaya mengarahkan (directive style) adalah gaya pengambilan keputusan yang dicirikan oleh toleransi yang rendah terhadap ambiguitas dan cara berpikir yang rasional, (2) gaya analitis (analytic style) adalah gaya pengambilan keputusan yang dicirikan oleh toleransi terhadap ambiguitas yang tinggi dan berpikir rasional, (3) gaya konseptual (Conceptual style) adalah gaya pengambilan keputusan yang dicirikan oleh toleransi terhadap ambiguitas yang tinggi dan cara berpikir intuitif, 
(4) gaya perilaku (Behavioral style) adalah gaya pengambilan keputusan yang dicirikan oleh toleransi terhadap ambiguitas yang rendah dan cara berpikir intuitif

Langkah pengambilan keputusan sebagai berikut: (1) Tahap identifikasi, di mana pengenalan masalah atau kesempatan muncul dan diagnosis dibuat Diketahui bahwa masalah yang berat mendapatkan diagnosis yang ekstensif dan sistematis, (2) Tahap pengembangan, di mana terdapat pencarian prosedur atau solusi standar yang ada, mendesain solusi yang baru, (3) Tahap seleksi, di mana pilihan solusi dibuat. Terdapat 3 (tiga) cara dalam pembentukan seleksi: dengan penilaian pembuat keputusan, berdasarkan pengalaman atau intuisi, bukan analisis logis; dengan analisis alternatif yang logis dan sistematis; dan dengan tawar-menawar saat seleksi melibatkan kelompok pembuat keputusan. Sekali keputusan diterima secara formal, otorisasi pun kemudian dibuat (Suparno, 2012).

Era globalisasi saat ini sumber daya manusia merupakan aspek penting dalam pencapaian suatu tujuan. Setiap organisasi atau perusahaan menjamin dipilihnya sumber daya manusia yang tepat dengan pekerjaan serta kondisi yang memungkinkan mereka bekerja optimal (Darmawan, 2003). lembaga pemerintah yang melaksanakan kekuasaan negara dalam bidang penuntutan dan penegakkan hukum harus menciptakan sumber daya manusia yang mampu bekerja secara efektif dan efisien demi mencapai tujuan yang ditetapkan. Untuk itu selalu berusaha untuk meningkatkan prestasi kerja pegawai agar supaya pegawai dapat meningkatkan kerja mereka dengan hasil prestasi yang dirasakan. Pengukuran terhadap tingkat prestasi kerja pegawai, penilaian prestasi kerja sangat penting dilakukan secara objektif kepada setiap pegawai. Prestasi kerja pegawai harus dilaksanakan secara efektif agar dapat menciptakan sumber daya manusia yang berkualitas. Konsep diri pegawai dinilai dapat mempengaruhi prestasi kerja pegawai, karena menjadi salah satu penentu dalam keberhasilan perkembangan adalah konsep diri. Konsep diri (Self Concept) merupakan suatu bagian yang penting dalam setiap pembicaraan tentang kepribadian manusia. Kebutuhan akan pendidikan dan pelatihan (diklat) merupakan faktor yang mempengaruhi prestasi kerja. Program pendidikan dan pelatihan (diklat) diterapkan oleh suatu organisasi dalam hal pengembangan pegawai sehingga mampu memberikan prestasi kerja yang optimal dan mampu mewujudkan tujuan organisasi. Disiplin kerja pegawai dinilai dapat mempengaruhi prestasi kerja pegawai. Siagian (2007) menyatakan bahwa disiplin merupakan tindakan manajemen untuk mendorong anggota organisasi memenuhi standar kerja yang ditetapkan, dalam hal ini adalah berprestasi kerja dengan baik. 
Komitmen Organisasional merupakan salah satu topik yang akan selalu menjadi tinjauan baik bagi pihak manajemen dalam sebuah organisasi maupun bagi para peneliti yang khususnya berfokus pada perilaku manusia. Komitmen Organisasional menjadi penting khususnya bagi organisasi yang ada saat ini dikarenakan dengan melihat sejauh mana keberpihakan seorang karyawan terhadap organisasi, dan sejauh mana karyawan tersebut berniat untuk memelihara keanggotaannya terhadap organisasi maka dapat diukur pula sebaik apa komitmen seorang karyawan terhadap organisasinya (Kartika, 2011).

Newstrom (2007) mengatakan bahwa

Komitmen Organisasional dapat juga dikatakan sebagai loyalitas karyawan, yang merupakan sebuah derajat yang mana seorang karyawan mengidentifikasikan diri terhadap organisasi dan ingin untuk melanjutkan berpartisipasi secara aktif dalam organisasi tersebut. Hal ini juga dapat untuk mengukur keinginan karyawan untuk tetap bertahan di masa yang akan datang, dan kecenderungan positif yang muncul dari karyawan adalah catatan kehadiran yang baik, ketaatan pada kebijakan organisasi, dan menurunnya tingkat perputaran karyawan.

Salah satu perspektif pendekatan pada Komitmen Organisasional adalah berdasarkan pada ikatan afektif karyawan terhadap organisasinya yang mana sudut pandang Komitmen Organisasional ini terkarakteristikan pada sebuah kepercayaan yang kuat dan penerimaan atas tujuan dan nilai yang dimiliki organisasi oleh karyawan; keinginan untuk menggunakan usaha yang lebih dengan mengatasnamakan organisasi; dan keinginan yang kuat untuk menjaga keanggotaan dalam organisasi.

\section{METODE PENELITIAN}

Metode penelitian ini menggunakan metode literature review. Data yang digunakan adalah data sekunder. Tipe studi yang direview adalah tujuh penelitian yang menggunakan variabel kepemimpinan transformasional kinerja dan motivasi karyawan. Kepemimpinan transformasional, motivasi dan kinerja adalah variabel yang dipilih untuk direview yang disusun melalui penelusuran artikel penelitian yang telah terpublikasi. Penelusuran dilakukan menggunakan Sinta, Science Direct, dan Google Schollar dengan kata kunci tiap variabel yang telah dipilih. Artikel yang ditemukakan dibaca dengan cermat untuk melihat apakah artikel memenuhi kriteria penulis untuk dijadikan sebagai literatur dalam penulisan literature review. Pencarian terbatas mulai dari tahun 2000 hingga tahun 2021 yang diakses fulltext dalam format pdf. Artikel yang memenuhui kriteria dianalisis, diekstraksi dan disintesis kemudian ditentukan evidence-nya. Dari hasil ekstraksi dan analisis diharapkan akan ditemukan sebuah kesimpulan yang dapat dijadikan dasar dalam upaya peningkatan manajemen sumber daya manusia melalui kepemimpinan transformasional ataupun upaya untuk meningkatkan kinerja. 


\section{HASIL DAN PEMBAHASAN}

Persepsi menurut Philip Kotler dapat diartikan sebagai proses dimana individu memilih, memuaskan dan menafsirkan masukan informasi untuk menciptakan suatu gambaran yang berarti mengenai dunia. Sedangkan menurut Sobur, 2003 Persepsi adalah proses menerima, menyeleksi, megorganisasikan, mengartikan, menguji dan memberikan reaksi kepada rangsangan panca indra atau data.

Pengambilan keputusan adalah sebuah hasil dari pemecahan masalah, jawaban dari suatu pertanyaan sebagai hukum situasi, dan merupakan pemilihan dari salah satu alternatif dari alternatif-alternatif yang ada, serta pengakhiran dari proses pemikiran tentang masalah atau problema yang dihadapi. Adapun hasil dari pengambilan keputusan adalah keputusan (decision) Pengambilan keputusan memiliki dua fungsi yaitu: pangkal permulaan dari semua aktivitas manusia yang sadar dan terarah, baik secara individual maupun secara kelompok, baik secara institusional maupun secara organisasional, dan sesuatu yang bersifat futuristik, artinya bersangkut paut dengan hari depan, masa yang akan datang (efeknya atau pengaruhnya berlangsung cukup lama).

Proses mengambilan keputusan merupakan hal yang terpenting dalam berorganisasi untuk mendapatkan solusi yang terbaik karena mengambil keputusan adalah proses yang digunakan untuk memilih suatu tindakan sebagai alat, cara pemecahan masalah menghasilkan satu pilihan final dalam berorganisasi. Maka dari itu harus diadakanya musyawarah dalam mengatasi persoalan yang ada.

Konsep diri menurut Mulyana (2000) adalah pandangan individu mengenai siapa diri individu, dan itu bisa diperoleh lewat informasi yang diberikan lewat informasi yang diberikan orang lain pada diri individu. Schwartz (1992) mendeskripsikan bahwa nilai-nilai personal merupakan tujuan hidup yang berperan penting bagi kehidupan individu, mempengaruhi persepsi, melakukan justifikasi serta mengevaluasi perilaku. Nilai-nilai personal juga menempati posisi sentral dalam sistem kognitif individu dan untuk alasan ini nilai-nilai personal dapat mempengaruhi sikap kita, proses pengambilan keputusan, dan secara umum semua perilaku manusia.

Hakikat pengambilan keputusan. Pengambilan keputusan merupakan kegiatan penentuan alternatif. Karen ini berkaitan dengan fungsi dari manajemen. Seperti jika seorang leader melakukan planning, pengelolaan, dan kontroling maka akan membuat suatu keputusan. Ada beberapa ahli yang menjadi pelopor teori dan mengemukakan akan pengambilan keputusan tersebut misalnya teori manajemen 
yang dikemukakan oleh Fayol dan Urwick yang membahas tentang pengmbilan keputusan tentang pengaruhnya terhadap Otoritas dan delegasi.

Menurut Herbert A Simon sebagai ahli teori dalam keputusan dan organisasi yang merumuskan tiga tahapan utama dalam proses pengambilan keputusan, yaitu : (1) aktivitas Inteligensi, yakni sebagai tahap awal dalam pencarian kondisi organsiasi/ lingkungan yang memang membutuhkan pengambilan keputusan, (2) aktivitas Desain. Yakni tahapan yang mungkin ditemukan temuan-temuan akan pengembangan serta analisis masalah, (2) Aktivitas Memilih. Tahapan ini adalah tahapan terakhir adalah tahapan menentukan tahapan tindakan dari pilihan yang tersedia.

\section{Model Pengambilan Keputusan}

Ada beberapa pendekatan yang dilakukan oleh leader dalam hala ini biasanya manajer dalam melakukan suatu pengambilan keputusan umumnya dilakukan pada salah satu dari bebepara tipe yang ada dalam pengambilan keputusan, yaitu : (1) Model Klasik, (2) Model Administratif, dan (3) Model Politis

Pengambilan keputusan pada model klasik ini dilandasi pada asmusi, asumsi yang melandasi model ini adalah sebagai berikut (a) pengmabilan keputusan bertujuan unutk mencapai target yang telah diketahui dan disetujui, (b) pengambilan keputusan berusaha keras membuat kepastian, dan menghimun informasi dengan lengkap, (c) memahami kriteria untuk perkiraan altrenatif, dan (d) pengambil keputusan yaitu orang yang logis dalam memutuskan nilai guna membuat keputusan yang bisa mengoptimalkan target sasaran organsiasi

Model klasik ini tidak secara detail menerangkan tentang bagaimana seorang pengambilan keputusan melakukakn keputusan. Model ini hanya memberikan gambaran pembuat keputusan agar lebih logis. Pengambil keputusan yaitu orang yang logis dalam memutuskan nilai guna membuat keputusan yang bisa mengoptimalkan target sasaran organsiasi

Pada model Administratif, para manajer menjabarkan akan kondisi yang komplek dan mengambil keputusan secara actual bukan hanya sbatas memebrikan perintah akan tetapi bagiaman seharunsya mengambil keptusan yang ideal.

Model politis biasanya terjadi pada kondisi yang tidak pasti dan terbatasnya informasi maka manajer bisa menggunakan model ini dengan tahapan dalam proses pengambilan keputusan dilakukan melalui: (1) identifikasi masalah, (2) mendefinisikan masalah, (3) memformulasikan dan mengembangkan alternative, (4) pelaksanaan keputusan, dan (5) evaluasi keputusan. 


\section{Persepsi dalam Organisasi}

Persepi adalah merupakan cara untuk mengornagisasikan dan menjelaskan tentang kesan indera manusia supaya dapat memebrikan makna pada kondisi lingkungan mereka. Cara ini meliputi sensasi, atensi dan interpretasi. Luthans (2006) menjelaskan "persepsi adalah lebih kompleks dan lebi luas disbanding penginderaan". Proses persepsi mecakup porses interaksi yang rumit dari kegiatan seleksi, penyusunan bahkan penafsiran.

Demikian pula banyak faktor yang mempengaruhi persepsi, diantara factor yang mempengaruhi persepsi adalah: (1) psikologis, (2) famili, dan (3) kebudayaan.

Selain hal diatas ada juga factor fator yang berpengaruh terhadap suatu persepsi, factor itu ada factor dalam dan factor luar. Faktor luar yang memberikan dampak terhadap upaya penetapan persepsi adalah (a) Intensitas, besarnya dorongan intensitas dari luar maka akan besar pula terhadap hal tersebut untuk di fahami, (b) ukuran, (c) berlawanan atau kontras, (d) pengulangan, rangsan yang besar dari luar dan diulang-ulang terus maka bisa mempengaruhi perhatian besar pula dibandingkan dengan rangsangan yang hanya sekali dilihat dan didengar, dan (e) gerakan.

Adapaun faktor dalam yang memberikan dampak terhadap upaya penetapan persepsi adalah : pertama, belajar dan persepsi kedua, motivasi dan persepsi motivasi akan sangat mempengaruhi lahirnya persepsi ketiga, persepsi dan kepribadian karakter dan kualitas bahkan usia bisa memberikan pengaruh.

\section{Konsep diri}

Diri Hurlock dalam Ritandiyono \& Retnaningsih (2005) menyatakan bahwa konsep diri adalah gambaran yang dimiliki seseorang tentang dirinya. Brook dalam Ritandiyono \& Retnaningsih (2005) mengatakan bahwa konsep diri merupakan persepsi mengenai diri sendiri, baik bersifat fisik, sosial maupun psikologis, yang diperoleh melalui pengalaman individu dalam interaksinya dengan orang lain. Atwater dalam Desmita (2010) menyebutkan, konsep diri adalah keseluruhan gambaran diri, yang meliputi persepsi seseorang tentang diri, perasaan, keyakinan, dan nilai-nilai yang berhubungan dengan dirinya. Lebih lanjut Atwater dalam Desmita (2010) mengidentifikasi konsep diri atas tiga bentuk. Pertama, body image, kesadaran tentang tubuhnya, yaitu bagaimana seseorang melihat dirinya sendiri. Kedua, ideal self, yaitu bagaimana cita-cita dan harapan-harapan seseorang mengenai dirinya. Ketiga, social self, yaitu bagaimana orang lain melihat dirinya. 
Keberhasilan sesorang itu akan sangat mudah dicapai ketika konsep dirinya baik dan positif. Karena konsep diri yang baik dan positif maka akan bisa melahirkan sikap yang optimist, berani dalam melakukan hal baru. Bisa menanggung rsiko untuk sukses dan berani pula untuk gagal tentunya dengan penuh percaya diri, antusias bahkan berani untuk menentukan tujuan hidupnya serta selalu bersikap dan berfikir postif. Demikina pula sebaliknya seseorang akan susah untuk mecapai konsep dirinya ketika tidak ada rasa percaya diri bahkan selalu berfikir negative, bahkan tidak berani unutk mencoba hal-hal yang menantang dan baru, bahkan sikap dirinya merasa tidak berguna, bodoh bahkan pesimis.

\section{Kepempiminan Diri}

Kepemimpinan diri atau dikenal dengan istilah self leadership adalah merupakan pengembangan strategi yang di pusatkan pada tingkah laku, pikiran dan perasaan yang dipakai untuk menguasai atau mnegendalikan diri. Kepemimpinan diri ini juga dianggap bisa membentuk focus leadership. Self leadership ini merupakan sesuatu yang dilakukan oleh sesesorang untuk memimpin diri mereka sendiri. Setiap orang perlu untuk bisa berkreasi dan membuat perubahan, sebab perubahan bisa terjadi setiap saat.

Self leadership adalah bagian yang terpenting yang bisa mempengaruhi pandangan diri seseorang dalam membangun motivasi diri dan pembentuakn diri yang begitu dibutuhkan agar bisa bersikap sesuai dengan keadaan ideal yang diharapkan. Kepemimpinan diri dapat pula dijelaskan bahwa kememimpinan diri adala upaya untuk menata diri sendiri dan mengendalikan diri sendiri dalam membangun dorongan diri agar mampu untuk berprilaku yang baik dan sesuai dengan kondisi yang diinginkan.

\section{SIMPULAN}

Organisasi sebagai sebuah lembaga yang terdiri dari banyak orang, perlu memahami dengan benar akan fungsi dan pengaruh persepsi, pengambilan keputusan , konsepdiri dan value. Dimana kesemuanya sangat berkaitan dalam menyelaraskan semua karakter dalam organisasi, dan menciptakan sebuah budaya organisasi yang khas dalam suatu organisasi.

Pengambilan keputusan dalam organisasi dipengaruhi oleh persepsi, konsepdiri dan value dalam suatu organisasi, dimana jika semua variable ini memiliki nilai kualitas yang tinggi akan mempengaruhi kualitas pengambilan keputusan organisasi. Yang pada akhirnya berdampak pada hasil yang diinginkan.

Kepimimpinan yang kuat akan memberikan dampak yang besar terhadap kemajuan suatu organisasi, kepemimpinan yang lemah akan membuat organisasi kurang berkembang, karena tidak dapat menyelesaikan konflik yang ada dalam organisasi 


\section{REFERENSI}

Aulawi, Anton, and Srinawati Srinawati. (2019) "Implementasi Nilai-Nilai Demokrasi Dalam Pengambilann Keputusan Organisasi Untuk Meningkatkan Organisasi Siswa Intra Sekolah (OSIS) Di SMK Darus Syifa Kota Cilegon”. PRO PATRIA 2.1 (2019): 38-50.

Fauziah, Sifa. (2011) "Pengaruh konsep diri dan kepuasan kerja terhadap komitmen organisasi pada pegawai UIN Syarif Hidayatullah, Jakarta.

Gammahendra, Fianda. (2014) "Pengaruh struktur organisasi terhadap efektivitas organisasi (studi pada persepsi pegawai tetap Kantor perwakilan Bank Indonesia Kediri)." Jurnal Administrasi Bisnis 7.2

Han, Sia Tjun, et al. (2012) "Komitmen afektif dalam organisasi, perceived organizational support, dan kepuasan kerja." Jurnal manajemen dan kewirausahaan 14.2: 109-117.

Izzati, Anugerah, Umi. (2014) "Nilai-Nilai Personal Pembentuk Persepsi Dukungan Organisasi”. Jurnal Psikologi Teori \& Harapan. 4.2 (2014): 2087-1708

Lipursari, Anastasia. (2013) "Peran sistem informasi manajemen (SIM) dalam pengambilan keputusan." JURNAL STIE SEMARANG (EDISI ELEKTRONIK) 5.1 (2013): 26-37.

Mujiasih, Endah. (2015) "Hubungan antara persepsi dukungan organisasi (perceived organizational support) dengan keterikatan karyawan." Jurnal Psikologi 14.1: 40-51.

Meiyanto, Sito, and Fauzan Heru Santhoso. (1999) "Nilai-nilai kerja dan komitmen organisasi: Sebuah studi dalam konteks pekerja Indonesia." Jurnal Psikologi 26.1 (1999): $29-40$.

Nurrohim, Hassa, and Lina Anatan. "Efektivitas komunikasi dalam organisasi." Jurnal Manajemen Maranatha 8.2 (2009): 11-20.

Nisak, Fahrun. Pengaruh Pengetahuan, Keterampilan, Konsep Diri Dan Karakteristik Pribadi Terhadap Kinerja Staf Pada Smk N Se-Kota Pekalongan. Diss. UNIVERSITAS NEGERI SEMARANG, 2015.

Novilita, Hairina. "Konsep Diri Adversity Quotient Dan Kemandirian Belajar Siswa". Jurnal Psikologi. 8.1 (2013): 619-632

Nurtjahjani, Harlina. "Spiritualitas kerja sebagai ekspresi keinginan diri karyawan untuk mencari makna dan tujuan hidup dalam organisasi." Jurnal Psikologi 7.1 (2010): 27-30.

Putra, Vajar Makna. "Persepsi Guru Terhadap Pengambilan Keputusan Kepala Sekolah di SMK Negeri Kelompok Bisnis Manajemen Kota Padang." Jurnal Bahana Manajemen Pendidikan 2.1 (2020): 755-763.

Putra, Vajar Makna. "Persepsi Guru Terhadap Pengambilan Keputusan Kepala Sekolah di SMK Negeri Kelompok Bisnis Manajemen Kota Padang." Jurnal Bahana Manajemen Pendidikan 2.1 (2020): 755-763.

Pashar, Imran, and Luky Dwiantoro. "Pengaruh empowerment terhadap pengambilan keputusan perawat: Kajian literature review." Journal of Holistic Nursing Science 7.2 (2020): 124-132. 
Pratiwi, Kurniasari, and Fathul Himam. "Kualitas kehidupan kerja ditinjau dari kepuasan kerja dan persepsi terhadap kinerja." Jurnal Psikologi Undip 13.1 (2014): 42-49.

Saud, Ilham Maulana. "Pengaruh sikap dan persepsi kontrol perilaku terhadap niat whistleblowing internal-eksternal dengan persepsi dukungan organisasi sebagai variabel pemoderasi." Journal of Accounting and Investment 17.2 (2016): 209-219.

Semaraputri, S. A. K. T., and I. Made Rustika. "Peran problem focused coping dan konsep diri terhadap penyesuaian diri pada remaja akhir yang menjadi pengurus organisasi kemahasiswaan di fakultas kedokteran universitas udayana." Jurnal Psikologi Udayana 5.1 (2018): 35-47.

Sulistyo, Heru. "Peran nilai-nilai religiusitas terhadap kinerja karyawan dalam organisasi." Media Riset \& Manajemen 11.3 (2011): 252-270.

Soeyitno, Adisty Herwidaningtyas. "Hubungan antara persepsi karyawan terhadap gaya kepemimpinan partisipatif atasan dengan kinerja karyawan di RS Muji Rahayu Surabaya." Jurnal psikologi industri dan organisasi 2.2 (2013).

Tua, Adhytia G., Bernhard Tewal, and Merlyn Karuntu. "Konsep diri, Pendidikan dan pelatihan, disiplin kerja terhadap prestasi kerja pegawai di Kejaksaan tinggi Sulawesi Utara." Jurnal EMBA: Jurnal Riset Ekonomi, Manajemen, Bisnis dan Akuntansi 2.1 (2014).

Pudjo Sumedi,(2010). Organisasi dan Kepemimpinan, Jakarta, Uhamka Press

Ardana, Komang, dkk. 2008. Perilaku Keorganisasian. Yogyakarta: Graha Ilmu

Rivai, Veithzal, 2007. Kepemimpinan dan Perilaku Organisasi, Jakarta: PT. Raja Grafindo Persada.

Kamal, "Kepemimpinan dalam Organisasi, Nopember 2009)

Roman, "Peran Kepemimpinan dalam Pengambilan Putusan, (21 Nopember 2009)

Daft Richard L. 2002. Manajamen: Edisi kelima. Jakarta: PT. Erlangga.

Rivai Veithzal. 2007. Kepemimpinan dan Perilaku Organisasi. Jakarta: PT. Raja Grafindo Persada.

Siagian Sondang P. 2008. Filsafat Administrasi. Jakarta: PT. Bumi Aksara. 